\title{
Nettbasert veiledning i anamneseopptak og klinisk undersøkelse
}

Hva gjør smågruppelæreren hvis pasienten ikke orker å delta i studentundervisningen? Og hva gjør legestudenten som er syk og må bli hjemme? JournalWiki er en nyutviklet norsk nettressurs som supplerer undervisningen ved å demonstrere undersøkelsesteknikk og kliniske funn via Internett. MediaWiki-plattformen, best kjent gjennom Wikipedia, er brukervennlig og tillater alle å bidra med innhold og forbedringer. En fagredaksjon kan overvåke alle endringer og kvalitetssikre innholdet.

\section{Nina Elisabeth Madsen}

Ingunn Marie Randulff Nielsen

Det medisinske fakultet

Universitetet i Oslo

\section{Lars Aabakken}

Det medisinske fakultet

Universitetet i Oslo

og

Gastromedisinsk undersøkelse

Oslo universitetssykehus, Rikshospitalet

\section{Arne Westgaard*}

arne.westgaard@medisin.uio.no

Det medisinske fakultet

Universitetet i Oslo

og

Kirurgisk avdeling

Oslo universitetssykehus, Rikshospitalet

* Nåværende arbeidssted:

Kreftsenteret

Oslo universitetssykehus, Ullevål

0407 Oslo

Nettbaserte, multimedia læringsverktøy kan være et godt supplement til propedeutikkundervisningen i medisinstudiet (ramme 1). Engelskspråklige ressurser er ikke nødvendigvis i overensstemmelse med norske fagtradisjoner, og norske pasientjournaler må skrives med norske faguttrykk. Det finnes flere norske e-læringsressurser (1), men ingen som gir en helhetlig oversikt over anamneseopptak og klinisk undersøkelse.

Vi har laget en nettbasert læringsressurs, $w w w$.journalwiki.no, som støtte for ordinær undervisning i propedeutikk

\section{Teknisk plattform}

MediaWiki ble benyttet for å lage en wikibasert veiledning i anamneseopptak og klinisk undersøkelse (2). MediaWiki er en fritt tilgjengelig programvare som kan lastes ned via Internett. En wiki er et nettsted som er laget for at enhver skal kunne legge til eller endre innhold uten at man har kjennskap til programmering (3). Dette gjøres ved hjelp av et forenklet markeringsspråk. Wikipedia er kanskje det beste eksemplet på et slikt nettsted (4). Vi ga nettressursen navnet JournalWiki, installerte den på en www.journalwiki.no. Programvaren ble konfigurert slik at brukere skal kunne laste opp tekst og lenker, samt bilde- og mediefiler. Lange videosekvenser ble gjort tilgjengelige via direkte avspilling fra en streamingserver ved Universitetet i Oslo.

Utarbeiding av det faglige innholdet Deler av det faglige innholdet ble utviklet som ledd i en obligatorisk prosjektoppgave for to legestudenter ved Universitetet i Oslo Linux-server og gjorde den tilgjengelig via
(NEM og IMRN). Veileder (AW) har i seks år undervist i propedeutikk og klinisk undersøkelsesteknikk. Han skrev de generelle artiklene om bl.a. journalopptak, anamnese og status presens på bakgrunn av egen erfaring og utvalgt faglitteratur. Studentenes prosjektoppgave ble avgrenset til å utarbeide en interaktiv veiledning i undersøkelse av abdomen, hvor det ble lagt vekt på studentenes egne erfaringer fra nylig gjennomført propedeutikkundervisning. Veiledningen er tenkt som mal for tilsvarende veiledninger i undersøkelse av andre organsystemer (ramme 2).

Det faglige innholdet er basert på et utvalg av relevant litteratur (5-10) og samtaler med spesialister i allmennmedisin, indremedisin og kirurgi. Vi laget en skriftlig prosedyre for en standardisert undersøkelse av abdomen. Ved Foto- og videotjenesten, Oslo universitetssykehus, Rikshospitalet, gjorde vi videoopptak av mageundersøkelsen utført på en frisk person med en erfaren indremedisiner (LA) som instruktør. Det ble utarbeidet et samtykkeskriv til bruk ved fotografering og videoopptak av pasienter for demonstrasjon av kliniske funn. Presentasjon av journalutdrag på nettsiden er diskutert med personvernom-

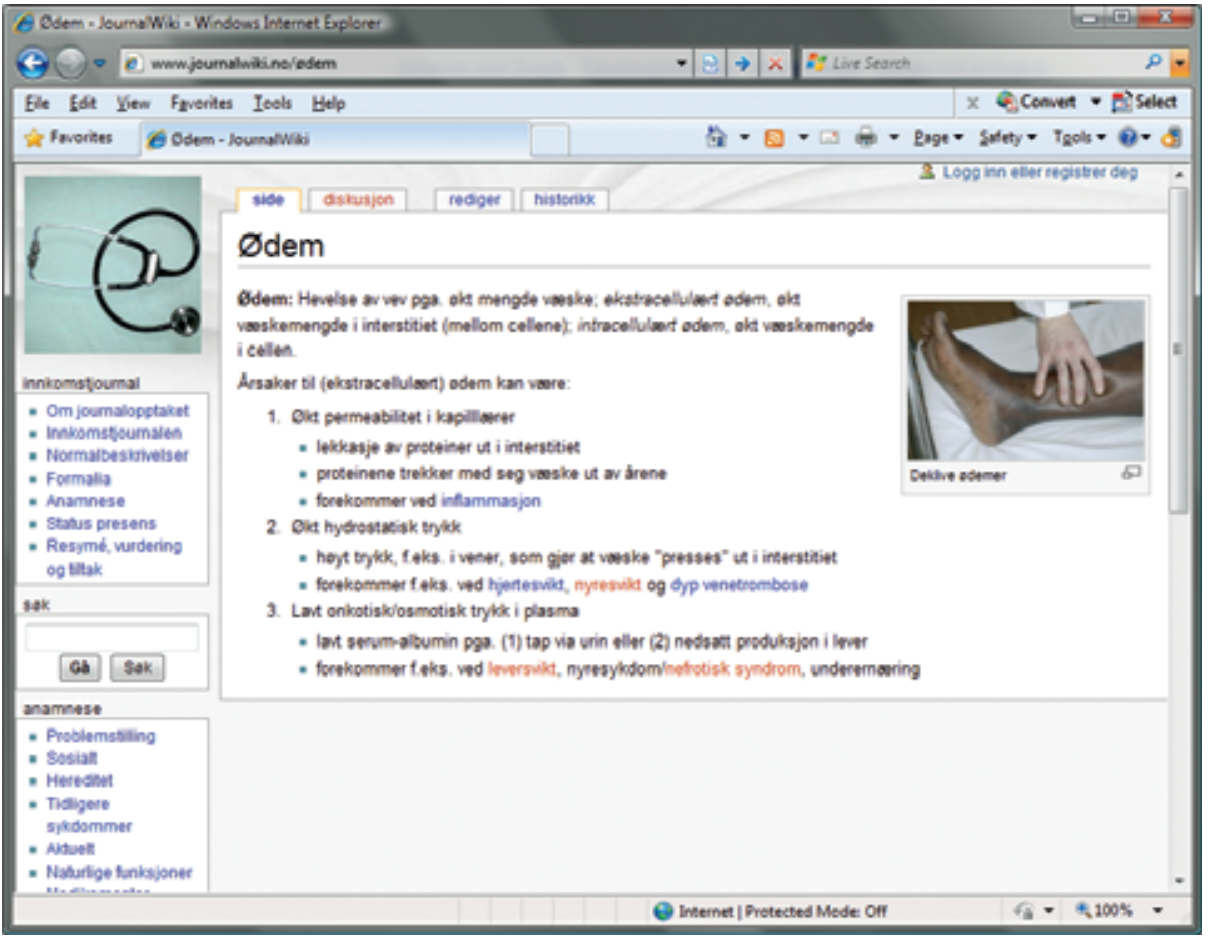

Figur 1 Eksempel på artikkel, i dette tilfellet en ordforklaring, i JournalWiki 


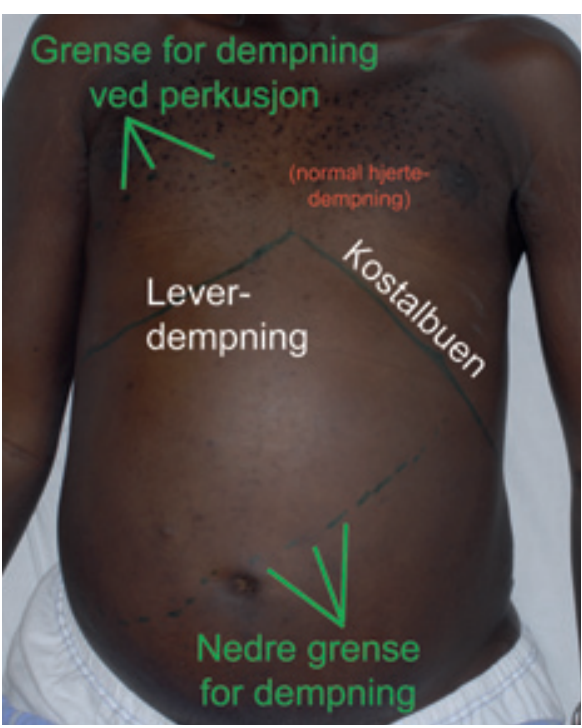

Figur 2 Pasient med en stor leversvulst. Bildet illustrerer hvor man fant dempning ved perkusjon og er et eksempel på bilder som er brukt i JournalWiki

budet, som mener opplysningene er tilstrekkelig anonymisert. Prosjektet er tilrådd av personvernombudet ved Rikshospitalet (11).

\section{MediaWiki som e-læringsplattform}

Vi fant MediaWiki-programvaren svært brukervennlig og fleksibel. Det kreves ikke høy kompetanse for å foreta systemvedlikehold, og enkelte funksjoner som ikke var implementert som standard, f.eks. innsetting av sluttreferanser med løpende nummerering i teksten, var lett tilgjengelige og enkle å installere (12). Programvaren kunne konfigureres slik at det var ulike nivåer av sikkerhet på hver enkelt artikkel og for hver enkelt bruker, og slik at det var lett å spore alle endringer i nettressursen for dermed å kunne kvalitetssikre det faglige innholdet.

JournalWiki er for tiden konfigurert slik at alle kan gjøre endringer og dermed bidra til det faglige innholdet i nettressursen. Alle som gjør endringer identifiseres med brukernavn eller IP-adresse, og endringene vises for en redaksjonskomité, for tiden LA og AW (13), som kan godkjenne eller forkaste det som er gjort. Ramme 3 viser hva vi la vekt på ved valg av teknisk løsning for læringsplattformen.

Figur 1 viser artikkelen om ødem og illustrerer noen av mulighetene programvaren gir. Etter innlogging kan man se oversikten over egne bidrag og listen over artikler man har angitt at man ønsker å overvåke. Videre kan man endre preferanser for bl.a. elektronisk kommunikasjon og grafisk utforming av nettsidene. Hver registrerte bruker har en egen diskusjonsside. Når andre brukere skriver innlegg, får man en melding om dette neste gang man besøker nettressursen. Man kan velge å motta e-post når artikler man ønsker å overvåke endres eller kommenteres. I artiklene er det faner øverst på siden med koblinger til redigering og diskusjon av artikkelen og artikkelens historikk. Redaksjonsmedlemmene kan via tilsvarende faner som bare er synlige for administratorer, slette innhold eller låse artikler for ytterligere endringer. I venstre marg er det snarveier til hovedsiden, navigasjonssider og hjelpesider.

\section{Innholdet i JournalWiki}

JournalWiki består i øyeblikket av over 200 artikler og utvides stadig. Artiklene er ordnet i kategorier og underkategorier. Hver av disse kategoriene presenteres på egne sider (kategorisider). Brukere kan navigere til artikler direkte fra disse sidene eller fra forsiden, og i tillegg er det en egen prosjektportal som bidrar med oversikt over nettstedet. Artiklene kan også finnes ved hjelp av den interne søkefunksjonen som er godt synlig på alle sider. På nettstedet finner man en fullstendig beskrivelse av journalopptak, inkludert formalia, anamnese og status presens, samt en standardmal for innkomstjournalen. Eksempler fra studenters journalopptak er lagt ved for å illustrere viktige poenger, og enkelte lovbestemmelser og god skikk i forbindelse med journalopptak omtales.

Besøkende kan enkelt navigere til nettsidene som omhandler undersøkelse av abdomen. Figur 2 viser et bilde som demonstrerer perkusjonsfunn hos en person med kraftig forstørret lever. Videoklipp tatt fra en annen pasient viser hvordan brokk protruderer ved hoste og ved undersøkelse i stående stilling.

\section{Et supplement}

\section{til klinisk undervisning}

Hensikten med denne e-læringsressursen i anamneseopptak og klinisk undersøkelsesmetodikk var å ta i bruk multimediaverktøy for å styrke undervisningen. I tillegg til kompendier og lærebøker kan interaktive læremidler, og spesielt video som demonstrerer fremgangsmåten ved klinisk undersøkelse, bidra til å standardisere undervisningen. Lokale ressurser og tilfeldige variasjoner i hvilke pasienter som er tilgjengelig for undervisningen fra gang til gang, kan dermed bli noe mindre avgjørende for det totale undervisningsutbyttet.

Mange undervisere har utarbeidet egne notater og lysbildepresentasjoner til bruk i studentundervisningen. Det kopieres også flittig fra lærebøker og nettressurser - med eller uten tillatelse. Programvareplattformen og nettressursen $w w w$.journalwiki.no gir en mulighet til å samordne undervisningsmateriell fra ulike bidragsytere. Faglærere kan bidra med artikler, bilder og videodemonstrasjoner innen sitt felt, og studenter kan være med på å utvikle veiledninger og annet stoff, kvalitetssikret av erfarne leger. Det er etablert kontakt med faglærere innen ulike disipliner, og prosjektet har mottatt midler til å videreutvikle nettressursen blant annet ved hjelp av lønnet arbeid fra studenter.

\section{Ramme 1}

Fordeler med nettbasert veiledning i propedeutikk

- Billig og oppdatert: Det koster mindre enn trykte lærebøker og er lettere å oppdatere

- Tilgjengelig: Nettressursen er tilgjengelig utenom ordinær undervisning og for mange brukere samtidig

- Multimedia: Tekst suppleres med bilder og video

- Interaktivt: Det finnes hyperlenker til ordforklaringer, bilder og quiz. Brukere kan åpent diskutere innholdet og gi tilbakemelding til lærere

\section{Ramme 2}

\section{Mal for interaktiv veiledning} i klinisk undersøkelse

- Film som viser en god undersøkelse av det aktuelle organsystem

- Tekst som beskriver de ulike delene av undersøkelsen

- Bilder med relevante kliniske funn

- Forklaringer på faglige ord og uttrykk som studentene vil kunne støte på i forbindelse med propedeutikkundervisningen

\section{Ramme 3}

Følgende momenter ble vektlagt ved valg av teknisk løsning for JournalWiki

- Brukervennlighet: Blant annet at brukeren ikke må installere tilleggsprogrammer for å benytte seg av tilbudet

- Tilgjengelighet: At nettstedet er konfigurert slik at søkemotorer lett kan identifisere og indeksere sidene

- Hastighet: At video og bilder ikke tar lang tid å laste opp

- Lite krav til teknisk kunnskap: At det skal være enkelt å vedlikeholde sidene

- Funksjonalitet: At produktet blir oversiktlig og at man har mulighet for å legge til de elementer som egner seg i en medisinsk læringsressurs

Som modell for videodemonstrasjonen av standardisert abdominal undersøkelse, valgte vi bevisst å bruke en frisk person i pasientrollen. Fremgangsmåten ved klinisk undersøkelse av abdomen vil kunne variere fra gang til gang, avhengig av 
aktuelle symptomer og sykehistorien. Undersøkelsesteknikk varierer også erfaringsmessig fra lege til lege. Vi kombinerte informasjon fra artikler, lærebøker og fagpersoner for å danne en mal for undersøkelse av abdomen som skulle være grundig og kunne bli allment akseptert blant ulike faglærere. Vi tror at et grunnverktøy som er mest mulig standardisert, vil kunne resultere i bedre undersøkelsesteknikk for legestudentene. Multimediaverktøyet må selvsagt suppleres med klinisk erfaring, slik at man lærer å tilpasse sin undersøkelse til den aktuelle pasient og problemstilling.

Programvaren MediaWiki har etter vårt syn fungert svært tilfredsstillende og fremstått som et godt egnet publikasjonsverktøy for denne typen nettressurser. Vi oppfordrer alle til å bidra med utviklingen av www.jounalwiki.no.
Vi takker Rolf Aamodt, Bjørgulf Claussen, Eilif Dahl, Ivar Gladhaug, Morten Hagness og Hanne Storm for faglige råd og synspunkter, samt Christian Nissen, Øyvind Omang og Joakim Magnus Taraldsen for teknisk hjelp.

Oppgitte interessekonflikter: Ingen

\section{Litteratur}

1. Universitetet i Oslo, Det medisinske fakultet. E-læring ved fakultetet. www.med.uio.no/studier/ elaring/ (12.3.2009).

2. MediaWiki. Welcome to MediaWiki.org. www.mediawiki.org/ (3.2.2009).

3. Wikipedia, the free encyclopedia. Wiki. en.wikipedia.org/w/index. php?title=Wiki\&oldid= 233253709 (21.8.2008)

4. Wikipedia. www.wikipedia.org (3.2.2009).

5. Penner RM, Majumdar SR. Diagnostic approach to abdominal pain in adults. I: Fletcher RH, Sokol HN, red. Waltham, MA: UpToDate, 2008. www.uptodate.com (21.8.2008).

6. Fishman MB, Aronson MD. Differential diagnosis of abdominal pain in adults. I: Fletcher RH, Sokol
HN red. Waltham MA: UpToDate, 2008. www.uptodate.com (21.8.2008).

7. Fishman MB, Aronson MD. History and physical examination in adults with abdominal pain. I: Fletcher RH, Sokol HN, red. Waltham, MA: UpToDate 2008. www.uptodate.com (21.8.2008)

8. Macleod J, Douglas G, Nicol EF et al. Macleod's Clinical examination. Edinburgh: Elsevier Churchill Livingstone, 2005.

9. Talley NJ, O'Connor S. Clinical examination: a systematic guide to physical diagnosis. Sydney: Elsevier Churchill Livingstone, 2006.

10. Bendz B, Eilertsen AL, Aabakken L et al. Journal 1 : om å skrive enda bedre medisinske journaler. Oslo: Unipub, 2005

11. JournalWiki: Personvern. www.journalwiki.no/ JournalWiki: Personvern (8.3.2009).

12. MediaWiki contributors. Extension: Cite MediaWiki, the free wiki engine. www.mediawiki.org/ wiki/Extension: Cite (12.3.2009).

13. JournalWiki: Redaksjon. www.journalwiki.no/JournalWiki: Redaksjon (8.3.2009).

Manuskriptet ble mottatt 4.9. 2008 og godkjent 19.3. 2009. Medisinsk redaktør Siri Lunde. 